\title{
The Competitiveness of Small and Medium Enterprises in Adverse Economic Environments
}

\author{
Thomas Poufinas $^{1 *}$, George Galanos ${ }^{1}$, Pyrros Papadimitriou ${ }^{2}$ \\ ${ }^{1}$ Department of Economics, Democritus University of Thrace, Komotini, Greece \\ ${ }^{2}$ Department of Political Science and International Relations, University of Peloponnese, Corinth, Greece \\ Email: *tpoufinas@gmail.com
}

How to cite this paper: Poufinas, T., Galanos, G. and Papadimitriou, P. (2018) The Competitiveness of Small and Medium Enterprises in Adverse Economic Environments. Theoretical Economics Letters, 8, 2788-2802.

https://doi.org/10.4236/tel.2018.813175

Received: July 23, 2018

Accepted: September 26, 2018

Published: September 29, 2018

Copyright () 2018 by authors and Scientific Research Publishing Inc. This work is licensed under the Creative Commons Attribution International License (CC BY 4.0).

http://creativecommons.org/licenses/by/4.0/

\begin{abstract}
Small and medium enterprises (SMEs) are the backbone of most economies and in particular of the economies of the European countries. They represent 99\% of all businesses in the European Union. They considered in total one of the biggest employers as they provided two thirds of the total private sector employment in the European Union (EU), where by EU we refer to the 28 countries of the European Union. These are Austria, Belgium, Bulgaria, Croatia, Cyprus, Czech Republic, Denmark, Estonia, Finland, France, Germany, Greece, Hungary, Ireland, Italy, Latvia, Lithuania, Luxembourg, Malta, Netherlands, Poland, Portugal, Romania, Slovakia, Slovenia, Spain, Sweden, and the United Kingdom. Furthermore, SMEs have a significant contribution from a social perspective; they provide employment to the vulnerable members of the society, such as less experienced, less educated and lower income workforce. However, SMEs were hit by the financial crisis with a notable number of them going out of business and suffering job losses. The latter were heavily concentrated in the Member States which were affected the most by the sovereign debt crisis. At the same time, compared to the large enterprises, SMEs appeared to be more resilient than large enterprises, particularly regarding employment. Consequently, a question that arises is how can SMEs weather the crisis and maintain their competitiveness in adverse economic environments. In this paper an attempt to address the issue of SME competitiveness in adverse economic environments is made, by investigating the relationship between the appropriate enterprise competitiveness metrics, as measured by their capacity to compete (quantity and cost requirements, time requirements, certification and standards, competitors), to connect (ICT requirements, linkages with customers, linkages with businesses, linkages with institutions) and to change (financing requirements, skills requirements, intellectual property requirements, innovation requirements) and country statistics, including the competitiveness of each particular country, as measured
\end{abstract}


by the unemployment rate, the unit labor cost, the total employment growth, the GDP (in billion USD), the GDP growth, the GDP per capita (in USD) and the competitiveness indicators (in terms of relative consumer prices and relative unit labor costs). The methodological approach relies on the use of linear regressions. In doing so, we expect to derive the country policies and dynamics that can help SMEs maintain their competitiveness and comparative advantages in periods during which the economies are not performing as well. This is quite important, in securing not only the viability but also the growth of SMEs, taking into consideration the importance of their contribution to the economies of their countries of domiciliation as exhibited above.

\section{Keywords}

Competitiveness, Small and Medium Enterprises, Crisis, Adverse Economic Environment

\section{Introduction}

Small and Medium sized Enterprises (SMEs) are the backbone of any economy. Their contribution to innovation-led economic growth and job creation has been of renewed interest in recent years. At present, SMEs contribute about 55\% of GDP and $65 \%$ of employment in the high income countries and over $90 \%$ of employment and 70\% of GDP in the middle income countries [1]. Worldwide SMEs are facing increasing competitive pressures that are compounded by unequal access to cutting edge technologies and scientific resources. The reality is that only a marginal of the global SMEs universe is able to exploit the opportunities created by globalization. Among European SMEs, modern technology innovators and adaptors constitute no more than $20 \%$ of Europe's SMEs; a percentage that's bound to be lower amongst developing countries [1].

When talking about European best practice in SME sector the examples are almost invariably drawn from the Irish experience [1]. This strengthens the belief that there is a link between the competitiveness of SMEs and the performance of a country, especially in adverse economic environments. Ireland has been a country that was hit by the recent economic crisis but has managed to weather it and is exhibiting since sustainable growth. At the same time it has attracted the spotlights as it has created an entrepreneurial environment with favorable conditions for SMEs. This is reflected in the relevant indices, as Ireland has among the top places in the European Union in terms of ease of doing business [2], freedom from corruption, index of economic freedom, fiscal freedom, labor freedom, trade freedom, investment freedom [3]. At the same time it exhibits among the lowest corporate income tax rates and the highest GDP growth rates after the crisis [4].

The natural question is what a country can do as far as its own performance is concerned-measured by the relevant statistics, metrics and indices-so as to 
establish and support the competitiveness of the SMEs domiciled in it. This question is of vital importance particularly in extended periods of economic crises that create hurdles for the enterprises.

In this paper we link the country macroeconomic figures with the SME competitiveness indicators so as to reveal the relation between the country performance and the SME competitiveness.

Before we proceed though we give a definition of what an SME is. According to the European Commission [5], the main factors determining whether an enterprise is an SME are 1) staff headcount 2) either turnover or balance-sheet total. This is presented in Table 1.

\section{Literature Review}

The existing literature on SME competitiveness primarily focuses on identifying the factors that are relevant to SME competitiveness and the determinants of its success. It emphasizes on the role of innovation as a key element of competitiveness and it mainly focuses at a country level.

Karaev et al. [6] examine the use of a cluster approach among SMEs as a tool for meeting their challenges related to globalization and trade liberalization, as well as investigating its contributing factor in the process of increasing their competitiveness. They practically perform a literature review of the existing publications as the time. They find that there is strong evidence to suggest that a cluster policy brings additional positive effect to existing SME policy in industrialized economies, but such effects have not been extensively researched in developing (transition) countries, particularly from the point of view of the SMEs, which are the main actors in the cluster development process, in relation to whether their performance has been improved as a result of cluster effects.

Singh et al. [7] identify the major areas of strategy development by SMEs for improving competitiveness of SMEs in globalised market. They review research papers, mainly from referred international journals to point out thrust areas of research. On the basis of their review, gaps are identified and a research agenda is proposed. They find that SMEs have not given due attention for developing their effective strategies in the past, that they are localized in functioning and on the export fronts they face many constraints due to the lack of resources and poor innovative capabilities. For sustaining their competitiveness, they have to

Table 1. SME definition.

\begin{tabular}{cccc}
\hline Company Category & Staff Headcount & Turnover & Balance Sheet Total \\
\hline Medium & $<250$ & $\leq 50$ Million EUR & $\leq 43$ Million EUR \\
Small & $<50$ & $\leq 10$ Million EUR & $\leq 10$ Million EUR \\
Micro & $<10$ & $\leq 2$ Million EUR & $\leq 2$ Million EUR \\
\hline
\end{tabular}

Source: European Commission [5]. 
benchmark their assets, processes and performance with respect to the best in industry and to develop a framework for quantifying the competitiveness by adopting a holistic approach.

Ruzzier et al. [8] attempt to understand the similarities and differences in the internationalization of SMEs and MNEs and the specific factors affecting them. They review the relevant literature particularly in the context of the major theories of internationalization. They present the positive and the negative aspects of each theoretical approach to internationalization to form the basis of a new model of international entrepreneurship.

Munir et al. [9] look at the sustainability of the competitive advantage of SMEs by studying the capabilities that they need to develop in order to achieve it. They use a sample of successful SMEs in leather, sports and surgical instruments clusters. They use field research to interview SME executives of successful manufacturing firms that are in business for a minimum of 15 to 20 years, in and around Sialkot, Pakistan.

Piatkowski [10] identifies factors that have a direct impact on the competitive position and the development of enterprises. In the analysis performed, a secondary research was employed, using the study of literature, research reports from various scientific centers and statistical data, as well as an empirical research conducted by means of a questionnaire with participation on a random sample of micro, small and medium enterprise located within southern and south-eastern Poland.

Utami and Lantu [11] aim at developing a model of competitiveness for SMEs, especially in the creative industry in Bandung, Indonesia. As a means to address the issue, they use depth interviews using semi-structured interviews. They rely on the output of the analysis to make recommendations to some of the interested parties, such as the business owners, the government, and the mediator in order to develop the SMEs.

Sener et al. [12] present the current state of SMEs in Turkey and investigate the global competitiveness strategies for them. The results of the study show that SMEs form $99.9 \%$ of the industry in Turkey however only 55\% of the SMEs are operating in value-adding sectors. They need dedicated financial support programs and policy initiatives for increasing their levels of global competitiveness. They look at the structure of the SMEs in Turkey compared to the European Union with regards to a series of drivers: entrepreneurial learning and women's entrepreneurship, bankruptcy and second chance for SMEs, regulatory framework for SME policy making, operational environment for SMEs, support services for SMEs and start-ups, public procurement, access to finance for SMEs, standards and technical regulations, enterprise skills, innovation policy for SMEs, SMEs in a green economy and internationalization of SMEs.

Ahmedova [13] analyzes the key factors for enhancing SME competitiveness and outlines the direction of their sustainable development in Bulgaria within the EU economic reality. She assesses the standard statistical indicators for the 
sector extended and improved by a nationally-representative empirical study into SMEs and research data from other studies, as well as EU reports.

Sag et al. [14] define factors that motivate or prevent the adoption of the open innovation approach by SMEs operating in developing countries, and to suggest policy requirements and actions need to be taken to ease the creation of an open innovation ecosystems that support SMEs. They recommend actions such as the incentive to leverage SME-university and SME-LE collaboration, the creation of innovation hubs to improve networking ability of SMEs, the free IP consulting and the conduct of external search on behalf of SMEs.

Soltes and Gavurova [15] provide a general picture of the innovation development of Slovakia as an accelerator of the competitiveness of SMEs. They present the basic directions and tendencies of development of the innovation system, with attention mainly on the lack of linkage between business sector and scientific research activities of universities. They deal with the financing of innovative development of SMEs, venture and development capital, which is in Slovak conditions used insufficiently. They also look at issues of innovation development in the healthcare sector and they bring selected partial results.

Stanislawski and Lisowska [16] determine the existing relations between openness to innovation (open innovation) and innovation potential. More specifically they examine the level of openness of SMEs (measured by propensity for cooperation with the environment), taking into account a number of variables, as well as the correlation (and its strength) between these two elements. They are based on the output of direct interviews with selected companies by means of the CATI method using a survey form. The study encompassed the companies in Poland which over the last three years conducted innovation activities involving the implementation of innovative solutions in different areas. Lisowska and Stanislawski [17] identify and assess the cooperation of small and medium enterprises with business institutions in the context of open innovation. The study verified positively the research hypothesis: The cooperation of small and medium enterprises with support institutions is at a low level, which is a serious barrier for the further innovative development of these entities in the context of open innovation.

Sipa et al. [18] point out and discuss the competitiveness determinants in polish small companies. They use the results of two direct studies of small and medium sized enterprises conducted in 2006-7 and 2013 with the use of questionnaires in SME companies in Poland. They come out with a series of factors, the most important of which seem to be company image-product brand, power of product price and focus on a specific group of customers.

The existing literature does not capture the relation of the SME competitiveness and the country macroeconomic figures, which is the objective of our paper. In our opinion unfolding this relation is important so as to understand what the countries need to do in order to increase the competitiveness of their SMEs. This is where the contribution of our research lies. 


\section{Problem Description}

The problem addressed is the effect of the country macroeconomic figures on the competitiveness of the SMEs of that country. The country economic activity figures selected are the population, the GDP (in USD billion), the GDP per capita (in USD), the share of world GDP (in PPP USD, \%), the current account surplus/deficit as share of GDP (in \%), the tariff preference margin (in percentage points), the imports and exports (of goods and services) as a share of GDP (in \%), the services exports as a share of total exports (in \%). The SME competitiveness is measured by their capacity to compete (quantity and cost requirements, time requirements, certification and standards, competitors), to connect (ICT requirements, linkages with customers, linkages with businesses, linkages with institutions) and to change (financing requirements, skills requirements, intellectual property requirements, innovation requirements).

We chose this approach as we observed that enterprises that are perceived as competitive in their majority happen to be in countries that exhibit themselves certain performance-competitiveness attributes. This means, that these countries exhibit superior ease of doing business [2], freedom from corruption, index of economic freedom, fiscal freedom, labor freedom, trade freedom, investment freedom [3]. At the same time they demonstrate among the lowest or most stable corporate income tax rates [4]. Entrepreneurs tend to prefer such countries; hence it is discussed among individuals who attempt to start business that those who choose such countries tend to have a competitive advantage. We try to find evidence of this belief in our paper.

In addition, securing SME competitiveness is important also for the country itself, as it is clearly to its benefit to for its SMEs to prosper due to their contribution to the country employment, growth and social well being.

\section{Data, Variables and Methodology}

\subsection{Data}

Our dataset consists of fifty countries (Argentina, Bangladesh, Barbados, Bhutan, Brazil, Burkina Faso, Cambodia, Chile, China, Colombia, Costa Rica, Côte d'Ivoire, Ecuador, Egypt, Ghana, Guinea, Hungary, India, Indonesia, Jamaica, Jordan, Kazakhstan, Kenya, Lebanon, Madagascar, Malawi, Malaysia, Mauritius, Mexico, Morocco, Namibia, Nepal, Nigeria, Paraguay, Peru, Poland, Russian Federation, Rwanda, Senegal, Slovakia, South Africa, Sri Lanka, Thailand, Trinidad and Tobago, Tunisia, Turkey, Ukraine, United Republic of Tanzania, Uruguay, Viet Nam). The relevant country figures are for 2017 and come from the International Trade Center [19]. Our interest is primarily in European countries; however we could not find the relevant data for a sufficient number of them. Six of the countries under investigation are European. Therefore, we included all countries for which SME competitiveness data were available.

\subsection{Variables}

The variables that are used as measures of SME competitiveness are the three 
pillars of the SME Competitiveness Grid of ICT; namely, the capacity to compete, the capacity to connect and the capacity to change.

To better explain the SME Competitiveness Grid of ICT, we borrow the relevant text form ICT [19]. The latter classifies the drivers according to 1) how they affect competitiveness with the use of 3 pillars and 2) where in the economy they intervene with the use of 3 levels. The 3 pillars and the 3 levels define the SME Competitiveness Grid.

The 3 pillars of competitiveness are the capacity to compete, connect and change. These reflect the traditional static and dynamic notions of competitiveness and emphasize on the importance of connectivity for competitiveness in modern economies [19]. These are in the vertical axis of the grid.

The 3 levels of the economy are the firm capabilities, the immediate business environment and the national environment. They put a focus on internal firm capabilities and the external local or sectoral environment of firms, i.e. the immediate business environment [19]. These are in the horizontal axis of the grid.

As per ICT [19], the capacity to compete focuses on the present operations of firms and their efficiency in terms of cost, time, quality and quantity. It extends to the immediate business and national environment. The capacity to compete refers to the static dimension of competitiveness. Examples of drivers include the use of internationally recognized quality certificates (firm capability), technical infrastructure accessible to firms (immediate business environment), and smooth customs procedures (macro-environment).

The capacity to connect focuses on gathering and exploiting information and knowledge. At the firm level, this refers to efforts to gather information flowing into the firm (e.g. consumer profiles, preferences and demand) and efforts to facilitate information flows from the firm (e.g. marketing and advertising). At the immediate business environment level, this includes links to sector associations, chambers of commerce etc. At the national level, capacity to connect is predominantly about the availability of ICT infrastructure. While capacity to connect is not strictly a time-sensitive phenomenon, information gathering and exploitation are so central to current and future competitiveness that they act as an essential link between the two pillars of static competitiveness and dynamic competitiveness.

The capacity to change focuses on the capacity of a firm to execute change in response to, or in anticipation of, dynamic market forces and to innovate through investments in human and financial capital. It incorporates the dynamic dimension of competitiveness. External factors change very rapidly, the only certainty is uncertainty. In this context, adaptation and resilience define competitiveness. Industry phases, breakthrough or disruptive innovations, increased competition and exchange-rate fluctuations are all events that require strategy adaptations. The capacity to change, for example, involves interpreting new market trends, the tactics of rivals, opportunities derived from new infrastructures or technologies, and governmental policies. 
Going now to the 3 levels of SME competitiveness [19], the firm capabilities level assesses whether firms have the capabilities to manage the resources under their control. Thus, this competitiveness level contains indicators to gauge whether firms follow best practices. For example, whether the firms have a bank account, use e-mails in day-to-day operations, or have high capacity utilization.

The immediate business environment delivers the resources and competencies that help to shape whether firms are competitive. Therefore, this level covers factors that are external to the firm but still within its micro-environment. Access to power, access to a skilled workforce or the vicinity of a relevant cluster of economic activities are examples of immediate business environment indicators.

Finally the national environment is important, as it establishes the fundamentals for the functioning of markets, government action in particular determines whether or not firm activities are facilitated. This level encompasses all structural factors that exist at the national level, such as policies on entrepreneurship and ease of doing business, trade-related policies, governance, infrastructure and resource endowments.

The SME Competitiveness Grid per country looks as in Table 2.

As we are interested in small and medium enterprises, we focus on the firm capability level, which is one out of three levels. These are the firm capacities (or capabilities), the business ecosystem and the national environment. We do that both for small and medium enterprises. These are our dependent variables.

We attempt to link them with the economic activity of the country as expressed by the population, the GDP (in USD billion), the GDP per capita (in USD), the share of world GDP (in PPP USD, \%), the current account surplus/deficit as share of GDP (in \%), the tariff preference margin (in percentage points), the imports and exports (of goods and services) as a share of GDP (in \%), the services exports as a share of total exports (in \%). These are our independent variables.

\subsection{Methodology}

We employ the use of linear regression in order to link the SME competitiveness indices described above with the economic activity in adverse economic environments. As our data are from the 2017 SME competitiveness outlook we are able to see how SMEs in the countries of interest weathered the crisis. The

Table 2. SME competitiveness grid per country.

\begin{tabular}{|c|c|c|c|c|}
\hline & \multirow{2}{*}{ SME Competitiveness Grid } & \multicolumn{3}{|c|}{ Pillars } \\
\hline & & Compete & Connect & Change \\
\hline \multirow{3}{*}{ Levels } & Firm capabilities & & & \\
\hline & Immediate business environment & & & \\
\hline & National environment & & & \\
\hline
\end{tabular}

Source: ICT [19]. 
regressions we run use one dependent and one independent variable. The general form of the regression equation is:

SME Competitiveness $=\beta_{0}+\beta_{1} \cdot v+u$

where SME Competitiveness stands for any of the three pillars of the SME Competitiveness Grid of ICT that we mention above and $v$ is any of the above variables of economic activity. We use the Stata econometric software to run these linear regressions with Ordinary Least Squares (OLS). We use White's test to detect potential heteroskedasticity and we use Robust Standard Errors to tackle it when present.

\section{Regressions}

We regressed for small and medium enterprises separately the capacity to compete, the capacity to connect and the capacity to change with the GDP, the GDP per capita, the share of world GDP, the current account surplus/deficit as share of GDP, the tariff preference margin, the imports and exports as a share of GDP (in \%), the services exports as a share of total exports individually (Table 3, Table 4).

\section{Results and Implications}

From the regressions of the medium enterprises capacity to compete index we realize that it is positively correlated at all levels with the GDP per capita, and at the $10 \%$ level with the current account surplus/deficit as a share of GDP. The remaining independent variablesseem to be statistically insignificant.

From the regressions of the medium enterprises capacity to connect index we see that it is positively correlated at all levels with the GDP per capita, whereas the remaining variables are not statistically significant.

From the regressions of the medium enterprises capacity to change we see that there is positive correlation with the current account surplus/deficit as a share of GDP at the 10\% significance level and positive correlation with the services exports as a share of total exports at all levels. The remaining variables are not statistically significant.

From the regressions of the small enterprises capacity to compete index we find that there is positive correlation with the GDP at the $5 \%$ significance level, with the GDP per capita and the current account surplus/deficit as percent of GDP at all levels and with the share of world GDP at the 10\% level. There is negative correlation at the $10 \%$ significance level with the tariff preference margin. All other variables are not statistically significant.

The regressions of the small enterprises capacity to connect index indicate that there is positive correlation with the GDP per capita only, which is statistically significant at all levels. The rest of the variables exhibit no statistical significance.

The regressions of the small enterprises capacity to change index show that there is positive correlation with the GDP per capita at all levels and with the services exports as a share of total exports and the $10 \%$ level. 
Table 3. Regressions summary—small enterprises.

(a)

\begin{tabular}{|c|c|c|c|c|c|c|c|c|}
\hline Variables/Regressions & (1) & (2) & (3) & $(4)$ & (5) & (6) & (7) & $(8)$ \\
\hline \multicolumn{9}{|l|}{ Dependent Variables } \\
\hline Compete & $\mathrm{X}$ & $\mathrm{X}$ & $\mathrm{X}$ & $\mathrm{X}$ & $\mathrm{X}$ & $\mathrm{X}$ & $\mathrm{X}$ & $\mathrm{X}$ \\
\hline \multicolumn{9}{|l|}{ Independent Variables } \\
\hline Population & $\begin{array}{l}0.0052463 \\
(0.98)\end{array}$ & & & & & & & \\
\hline GDP & & $\begin{array}{l}0.0016914^{\star \star} \\
\quad(2.03)\end{array}$ & & & & & & \\
\hline GDP per capita & & & $\begin{array}{l}0.0011583^{* * *} \\
\quad(4.81)\end{array}$ & & & & & \\
\hline Share of world GDP & & & & $\begin{array}{l}0.8991548^{*} \\
(1.77)\end{array}$ & & & & \\
\hline $\begin{array}{l}\text { Current account } \\
\text { surplus/deficit }\end{array}$ & & & & & $\begin{array}{l}0.5238997^{* * *} \\
(2.53)\end{array}$ & & & \\
\hline Tariff preference & & & & & & $-0.7713701^{\star}$ & & \\
\hline margin & & & & & & $(-1.70)$ & & \\
\hline $\begin{array}{l}\text { Imports and exports } \\
\text { goods and services }\end{array}$ & & & & & & & $\begin{array}{c}0.0342654 \\
(1.01)\end{array}$ & \\
\hline $\begin{array}{c}\text { Services exports share } \\
\text { of total }\end{array}$ & & & & & & & & $\begin{array}{c}-0.078998 \\
(-1.09)\end{array}$ \\
\hline Constant & $\begin{array}{l}38.95305^{* * *} \\
(26.16)\end{array}$ & $\begin{array}{c}38.63072^{* * *} \\
(27.32)\end{array}$ & $\begin{array}{c}32.634^{* * *} \\
(17.83)\end{array}$ & $\begin{array}{c}38.6096^{* * *} \\
(26.67)\end{array}$ & $\begin{array}{c}41.76821^{* * *} \\
(25.99)\end{array}$ & $\begin{array}{c}42.6601^{* * *} \\
(18.35)\end{array}$ & $\begin{array}{c}36.77203^{* * *} \\
(12.26)\end{array}$ & $\begin{array}{l}41.57188^{* * *} \\
(17.41)\end{array}$ \\
\hline Observations & 50 & 50 & 50 & 50 & 50 & 50 & 50 & 50 \\
\hline Adjusted R-squared & -0.0008 & 0.0597 & 0.3116 & 0.0420 & 0.0996 & 0.0372 & 0.0005 & 0.0037 \\
\hline
\end{tabular}

Notes: t-values in parenthesis; ${ }^{* *}$ statistically significant at the $1 \%$ level; ${ }^{* *}$ statistically significant at the $5 \%$ level; ${ }^{*}$ statistically significant at the $10 \%$ level. Source: Results of regressions run by the authors using data from the International Trade Center.

(b)

\begin{tabular}{|c|c|c|c|c|c|c|c|c|}
\hline Variables/Regressions & (9) & (10) & (11) & (12) & (13) & (14) & (15) & $(16)$ \\
\hline \multicolumn{9}{|l|}{ Dependent Variables } \\
\hline Connect & $\mathrm{X}$ & $\mathrm{X}$ & $\mathrm{X}$ & $\mathrm{X}$ & $\mathrm{X}$ & $\mathrm{X}$ & $\mathrm{X}$ & $\mathrm{X}$ \\
\hline \multicolumn{9}{|l|}{ Independent Variables } \\
\hline Population & $\begin{array}{c}-0.0008762 \\
(-0.08)\end{array}$ & & & & & & & \\
\hline GDP & & $\begin{array}{c}0.0012954 \\
(0.71)\end{array}$ & & & & & & \\
\hline GDP per capita & & & $\begin{array}{c}0.0026496^{* * *} \\
(5.51)\end{array}$ & & & & & \\
\hline Share of world GDP & & & & $\begin{array}{c}0.6302306 \\
(0.58)\end{array}$ & & & & \\
\hline $\begin{array}{l}\text { Current account } \\
\text { surplus/deficit }\end{array}$ & & & & & $\begin{array}{c}0.4759197 \\
(1.04)\end{array}$ & & & \\
\hline Tariff preference & & & & & & -0.5884914 & & \\
\hline margin & & & & & & $(-0.60)$ & & \\
\hline Imports and exports & & & & & & & 0.1076188 & \\
\hline goods and services & & & & & & & $(1.54)$ & \\
\hline $\begin{array}{l}\text { Services exports } \\
\text { share of total }\end{array}$ & & & & & & & & $\begin{array}{c}-0.030123 \\
(-0.20)\end{array}$ \\
\hline Constant & $\begin{array}{c}33.421^{\star \star *} \\
(10.60)\end{array}$ & $\begin{array}{c}32.69935^{* * *} \\
(10.64)\end{array}$ & $\begin{array}{c}17.71784^{* * \star} \\
(4.84)\end{array}$ & $\begin{array}{c}32.73854^{\star * *} \\
(10.48)\end{array}$ & $\begin{array}{c}35.431^{* * *} \\
(9.99)\end{array}$ & $\begin{array}{c}35.77589^{* * *} \\
(7.15)\end{array}$ & $\begin{array}{c}24.8875^{* * *} \\
(4.01)\end{array}$ & $\begin{array}{c}34.14052^{* * *} \\
(6.74)\end{array}$ \\
\hline Observations & 50 & 50 & 50 & 50 & 50 & 50 & 50 & 50 \\
\hline Adjusted R-squared & -0.0207 & -0.0101 & 0.3746 & -0.0138 & 0.0018 & -0.0132 & 0.0271 & --0.0200 \\
\hline
\end{tabular}

Notes: $\mathrm{t}$-values in parenthesis; ${ }^{* *}$ statistically significant at the $1 \%$ level; ${ }^{* *}$ statistically significant at the $5 \%$ level; ${ }^{*}$ statistically significant at the $10 \%$ level. Source: Results of regressions run by the authors using data from the International Trade Center. 
(c)

\begin{tabular}{|c|c|c|c|c|c|c|c|c|}
\hline Variables/Regressions & (17) & (18) & (19) & (20) & (21) & (22) & (23) & (24) \\
\hline \multicolumn{9}{|l|}{ Dependent Variables } \\
\hline Change & $\mathrm{X}$ & $\mathrm{X}$ & $\mathrm{X}$ & $\mathrm{X}$ & $\mathrm{X}$ & $\mathrm{X}$ & $\mathrm{X}$ & $\mathrm{X}$ \\
\hline \multicolumn{9}{|l|}{ Independent Variables } \\
\hline Population & $\begin{array}{c}0.0032273 \\
(0.61)\end{array}$ & & & & & & & \\
\hline GDP & & $\begin{array}{l}0.0006881 \\
(0.81)\end{array}$ & & & & & & \\
\hline GDP per capita & & & $\begin{array}{c}0.0007949^{* * *} \\
(3.00)\end{array}$ & & & & & \\
\hline Share of world GDP & & & & $\begin{array}{c}0.3838578 \\
(0.75)\end{array}$ & & & & \\
\hline $\begin{array}{l}\text { Current account } \\
\text { urplus/deficit }\end{array}$ & & & & & $\begin{array}{c}-0.1363437 \\
(-0.63)\end{array}$ & & & \\
\hline Tariff preference & & & & & & 0.0951586 & & \\
\hline margin & & & & & & $(0.21)$ & & \\
\hline $\begin{array}{l}\text { Imports and exports } \\
\text { goods and services }\end{array}$ & & & & & & & $\begin{array}{c}-0.0042443 \\
(-0.13)\end{array}$ & \\
\hline $\begin{array}{c}\text { Services exports share } \\
\text { of total }\end{array}$ & & & & & & & & $\begin{array}{c}0.1349596^{*} \\
\quad(1.93)\end{array}$ \\
\hline Constant & $\begin{array}{l}34.09091^{* * *} \\
(23.08)\end{array}$ & $\begin{array}{l}34.06581^{* * *} \\
(23.61)\end{array}$ & $\begin{array}{c}29.71866^{\star * *} \\
(14.73)\end{array}$ & $\begin{array}{l}34.0401^{* * *} \\
(23.24)\end{array}$ & $\begin{array}{l}33.80381^{* * *} \\
(20.12)\end{array}$ & $\begin{array}{l}34.00947^{\star * *} \\
(14.41)\end{array}$ & $\begin{array}{l}34.7372^{* * *} \\
(11.62)\end{array}$ & $\begin{array}{l}30.7995^{\star * *} \\
(13.42)\end{array}$ \\
\hline Observations & 50 & 50 & 50 & 50 & 50 & 50 & 50 & 50 \\
\hline Adjusted R-squared & -0.0130 & -0.0071 & 0.1402 & -0.0090 & -0.0124 & -0.0199 & --0.0205 & 0.0529 \\
\hline
\end{tabular}

Notes: $\mathrm{t}$-values in parenthesis; ${ }^{* * *}$ statistically significant at the $1 \%$ level; ${ }^{* *}$ statistically significant at the $5 \%$ level; ${ }^{*}$ statistically significant at the $10 \%$ level. Source: Results of regressions run by the authors using data from the International Trade Center.

We tested the above regressions for heteroskedasticity. To detect this we used White's test to find that no regressions seem to exhibit heteroskedasticity (violating the $10 \%$ threshold, although not the $1 \%$ level).

The above regression results yield a lot of similarities between small and medium enterprises as far as their competitiveness is concerned. As a first interpretation of our findings we can say that the small and medium enterprise competitiveness is strongly linked with the key macroeconomic figures of the country of domiciliation. This means that countries that have high GDP (both in monetary terms as well as in terms of share of the world GDP) and GDP per capita, as well as current account surplus seem to have more competitive SMEs. Tariff preference margin is negatively correlated for some of the SME competitiveness indices, indicating that limitations can pose hurdles also the local SMEs. What is interesting is that SME competitiveness is positively correlated with the service exports as a share of total exports. This means that countries that manage to market successfully their services abroad give to their SMEs a competitive advantage.

Considering the above for a country that has been hit by the crisis, for example Greece, which has lost approximately one quarter of its SMEs during the crisis [20], it seems that the country needs to focus to the basics; namely reverse the declining GDP and GDP per capita trend. In addition, as SMEs in Greece are mainly offering services, the country needs to support the promotion of these 
Table 4. Regressions summary-medium enterprises.

(a)

\begin{tabular}{|c|c|c|c|c|c|c|c|c|}
\hline Variables/Regressions & (1) & (2) & (3) & (4) & (5) & (6) & (7) & (8) \\
\hline \multicolumn{9}{|l|}{ Dependent Variables } \\
\hline Compete & $\mathrm{X}$ & $\mathrm{X}$ & $\mathrm{X}$ & $\mathrm{X}$ & $\mathrm{X}$ & $\mathrm{X}$ & $\mathrm{X}$ & $\mathrm{X}$ \\
\hline \multicolumn{9}{|l|}{ Independent Variables } \\
\hline Population & $\begin{array}{c}0.0006773 \\
(0.11)\end{array}$ & & & & & & & \\
\hline GDP & & $\begin{array}{c}0.0011986 \\
(1.28)\end{array}$ & & & & & & \\
\hline GDP per capita & & & $\begin{array}{l}0.0014565^{* * *} \\
(6.04)\end{array}$ & & & & & \\
\hline Share of world GDP & & & & $\begin{array}{c}0.5470139 \\
(0.97)\end{array}$ & & & & \\
\hline $\begin{array}{l}\text { Current account } \\
\text { surplus/deficit }\end{array}$ & & & & & $\begin{array}{l}0.4535903 \\
(1.96)\end{array}$ & & & \\
\hline Tariff preference & & & & & & -0.0784102 & & \\
\hline margin & & & & & & $(-0.15)$ & & \\
\hline $\begin{array}{l}\text { Imports and exports } \\
\text { goods and services }\end{array}$ & & & & & & & $\begin{array}{c}0.0056026 \\
(0.15)\end{array}$ & \\
\hline $\begin{array}{c}\text { Services exports share } \\
\text { of total }\end{array}$ & & & & & & & & $\begin{array}{l}0.0507298 \\
(0.63)\end{array}$ \\
\hline Constant & $\begin{array}{l}50.54029^{* * *} \\
(30.76)\end{array}$ & $\begin{array}{l}50.01692^{* * *} \\
(31.61)\end{array}$ & $\begin{array}{c}42.02073^{* * *} \\
(22.88)\end{array}$ & $\begin{array}{l}50.08743^{* * *} \\
\quad(30.98)\end{array}$ & $\begin{array}{l}52.6027^{* * *} \\
(29.25)\end{array}$ & $\begin{array}{l}50.93109^{* * *} \\
(19.48)\end{array}$ & $\begin{array}{l}50.16617^{* * *} \\
\quad(15.15)\end{array}$ & $\begin{array}{l}49.25111^{* * *} \\
(18.73)\end{array}$ \\
\hline Observations & 50 & 50 & 50 & 50 & 50 & 50 & 50 & 50 \\
\hline Adjusted R-squared & -0.0206 & 0.0130 & 0.4196 & -0.0013 & 0.0548 & -0.0203 & -0.0204 & -0.0123 \\
\hline
\end{tabular}

Notes: t-values in parenthesis; ${ }^{* * *}$ statistically significant at the $1 \%$ level; ${ }^{* *}$ statistically significant at the $5 \%$ level; ${ }^{*}$ statistically significant at the $10 \%$ level. Source: Results of regressions run by the authors using data from the International Trade Center.

(b)

\begin{tabular}{|c|c|c|c|c|c|c|c|c|}
\hline Variables/Regressions & (9) & (10) & (11) & (12) & (13) & (14) & (15) & $(16)$ \\
\hline \multicolumn{9}{|l|}{ Dependent Variables } \\
\hline Connect & $\mathrm{X}$ & $\mathrm{X}$ & $\mathrm{X}$ & $\mathrm{X}$ & $\mathrm{X}$ & $\mathrm{X}$ & $\mathrm{X}$ & $\mathrm{X}$ \\
\hline \multicolumn{9}{|l|}{ Independent Variables } \\
\hline Population & $\begin{array}{c}-0.0017241 \\
(-0.16)\end{array}$ & & & & & & & \\
\hline GDP & & $\begin{array}{l}0.0012254 \\
(0.70)\end{array}$ & & & & & & \\
\hline GDP per capita & & & $\begin{array}{c}0.0025799^{* * *} \\
(5.53)\end{array}$ & & & & & \\
\hline Share of world GDP & & & & $\begin{array}{l}0.5496526 \\
(0.52)\end{array}$ & & & & \\
\hline $\begin{array}{l}\text { Current account } \\
\text { surplus/deficit }\end{array}$ & & & & & $\begin{array}{c}0.1964768 \\
(0.44)\end{array}$ & & & \\
\hline Tariff preference & & & & & & -0.2517328 & & \\
\hline margin & & & & & & $(-0.26)$ & & \\
\hline $\begin{array}{l}\text { Imports and exports } \\
\text { goods and services }\end{array}$ & & & & & & & $\begin{array}{c}0.050231 \\
(0.73)\end{array}$ & \\
\hline $\begin{array}{c}\text { Services exports share } \\
\text { of total }\end{array}$ & & & & & & & & $\begin{array}{c}-0.0336443 \\
(-0.22)\end{array}$ \\
\hline Constant & $\begin{array}{c}54.26126^{* * *} \\
(17.72)\end{array}$ & $\begin{array}{c}53.49172^{\star * *} \\
(17.92)\end{array}$ & $\begin{array}{c}38.88621^{\star * *} \\
(10.96)\end{array}$ & $\begin{array}{c}53.57293^{* * *} \\
(17.65)\end{array}$ & $\begin{array}{c}54.95889^{* * *} \\
(15.80)\end{array}$ & $\begin{array}{c}55.13768 \\
(11.31)\end{array}$ & $\begin{array}{c}50.15066 \\
(8.17)\end{array}$ & $\begin{array}{c}54.99257^{* * *} \\
(11.18)\end{array}$ \\
\hline Observations & 50 & 50 & 50 & 50 & 50 & 50 & 50 & 50 \\
\hline Adjusted R-squared & -0.0203 & -0.0106 & 0.3768 & -0.0152 & -0.0168 & -0.0193 & -0.0098 & -0.0198 \\
\hline
\end{tabular}

Notes: t-values in parenthesis; ${ }^{* *}$ statistically significant at the $1 \%$ level; ${ }^{* *}$ statistically significant at the $5 \%$ level; ${ }^{*}$ statistically significant at the $10 \%$ level. Source: Results of regressions run by the authors using data from the International Trade Center. 
(c)

\begin{tabular}{|c|c|c|c|c|c|c|c|c|}
\hline Variables/Regressions & (17) & (18) & (19) & (20) & (21) & $(22)$ & (23) & $(24)$ \\
\hline \multicolumn{9}{|l|}{ Dependent Variables } \\
\hline Change & $\mathrm{X}$ & $\mathrm{X}$ & $\mathrm{X}$ & $\mathrm{X}$ & $\mathrm{X}$ & $\mathrm{X}$ & $\mathrm{X}$ & $\mathrm{X}$ \\
\hline \multicolumn{9}{|l|}{ Independent Variables } \\
\hline Population & $\begin{array}{l}0.0011367 \\
(0.19)\end{array}$ & & & & & & & \\
\hline GDP & & $\begin{array}{c}0.0006747 \\
(0.69)\end{array}$ & & & & & & \\
\hline GDP per capita & & & $\begin{array}{c}0.0003294 \\
(1.00)\end{array}$ & & & & & \\
\hline Share of world GDP & & & & $\begin{array}{c}0.2509555 \\
(0.42)\end{array}$ & & & & \\
\hline $\begin{array}{l}\text { Current account } \\
\text { surplus/deficit }\end{array}$ & & & & & $\begin{array}{c}-0.4507339^{*} \\
(-1.87)\end{array}$ & & & \\
\hline $\begin{array}{c}\text { Tariff preference } \\
\text { margin }\end{array}$ & & & & & & $\begin{array}{c}0.7176385 \\
(1.39)\end{array}$ & & \\
\hline $\begin{array}{l}\text { Imports and exports } \\
\text { goods and services }\end{array}$ & & & & & & & $\begin{array}{c}-0.0413187 \\
(-1.08)\end{array}$ & \\
\hline $\begin{array}{l}\text { Services exports share } \\
\text { of total }\end{array}$ & & & & & & & & $\begin{array}{c}0.2004087^{* * *} \\
(2.57)\end{array}$ \\
\hline Constant & $\begin{array}{l}50.52373^{* * *} \\
(29.70)\end{array}$ & $\begin{array}{c}50.30239^{* * *} \\
(30.33)\end{array}$ & $\begin{array}{l}48.69212^{* * *} \\
(19.50)\end{array}$ & $\begin{array}{l}50.39609^{* * *} \\
(29.86)\end{array}$ & $\begin{array}{l}48.64987^{* * *} \\
(26.03)\end{array}$ & $\begin{array}{l}47.65867^{* * *} \\
(17.94)\end{array}$ & $\begin{array}{c}53.87769^{* * *} \\
(15.90)\end{array}$ & $\begin{array}{l}45.28149^{* * *} \\
\quad(17.66)\end{array}$ \\
\hline Observations & 50 & 50 & 50 & 50 & 50 & 50 & 50 & 50 \\
\hline Adjusted R-squared & -0.0201 & -0.0108 & 0.0002 & -0.0170 & 0.0488 & 0.0184 & 0.0034 & 0.1026 \\
\hline
\end{tabular}

Notes: $\mathrm{t}$-values in parenthesis; ${ }^{* *}$ statistically significant at the $1 \%$ level; ${ }^{* *}$ statistically significant at the $5 \%$ level; ${ }^{*}$ statistically significant at the $10 \%$ level. Source: Results of regressions run by the authors using data from the International Trade Center.

services abroad. With the reduced labor and pension cost it has achieved over the last few years these services are affordable to other countries. Moreover, the entrepreneurs and the employees are qualified professionals and as such can offer high standard services.

\section{Conclusions}

In this paper, we study the capacity of SMEs to remain competitive in years of adverse economic conditions. The limitations of our effort stem from the fact that we could not find sufficient data for all the European countries. It is part of our ongoing research to identify such data and manage to look for evidence pertaining specifically to the European countries. In addition, we leave for future research the investigation for more years, as we only had access to competitiveness data for one year. This would allow us to clearly separate the periods of crisis from the non-crisis periods. Last but not least, we will further research additional macroeconomic or company specific variables that affect the SME competitiveness.

What we however saw in this paper is that SME competitiveness is vital not only for the SMEs themselves but also for the countries they domicile. It is therefore of great importance to identify the characteristics of economic activity that countries with successful SMEs exhibit. In this paper, we were able to show that SME competitiveness is definitely linked to the country performance as 
measured by the GDP, the GDP per capita, current account surplus/deficit as a share of GDP, the service exports as a share of total exports and the tariff preference margin. Consequently, a country that wishes to foster SME competitiveness needs to pay attention to the development of these figures and make sure they move to the appropriate direction.

\section{Conflicts of Interest}

The authors declare no conflicts of interest regarding the publication of this paper.

\section{References}

[1] International Development Ireland (2018) SME Competitiveness/Performance. https://www.idi.ie/sector/sme-competitiveness-performance

[2] Doing Business (2017). http://www.doingbusiness.org/rankings

[3] Miller, T. and Kim, A.B. (2016) Index of Economic Freedom-Promoting Economic Opportunity and Prosperity. Institute for Economic Freedom and Opportunity, The Heritage Foundation-In Partnership with The Wall Street Journal (2016).

[4] OECD (2017). http://stats.oecd.org/

[5] European Commission (2017) What Is an SME? http://ec.europa.eu/growth/smes/business-friendly-environment/sme-definition

[6] Karaev, A., Koh, S.C.L. and Szamosi, L. (2007) The Cluster Approach and SME Competitiveness: A Review. Journal of Manufacturing Technology Management, 18, 818-835. https://doi.org/10.1108/17410380710817273

[7] Singh, R.K., Garg, S.K. and Deshmukh, S.G. (2008) Strategy Development by SMEs for Competitiveness: A Review. Benchmarking: An International Journal, 15, 525-547.

[8] Ruzzier, M., Hisrich R.D. and Antoncic, B. (2006) SME Internationalization Research: Past, Present, and Future. Journal of Small Business and Enterprise Development, 13, 476-497. https://doi.org/10.1108/14626000610705705

[9] Munir, A., Lim, M.K. and Knigh, L. (2011) Sustaining Competitive Advantage in SMEs. Procedia-Social and Behavioral Sciences, 25, 408-412. https://doi.org/10.1016/j.sbspro.2012.02.052

[10] Piatkowski, M. (2012) Factors Strengthening the Competitive Position of SME Sector Enterprises. An Example for Poland. Procedia-Social and Behavioral Sciences, 58, 269-278. https://doi.org/10.1016/j.sbspro.2012.09.1001

[11] Utami, R.M. and Lantu, D.C. (2014) Development Competitiveness Model for Small-Medium Enterprises among the Creative Industry in Bandung. ProcediaSocial and Behavioral Sciences, 115, 305-323. https://doi.org/10.1016/j.sbspro.2014.02.438

[12] Sener, S., Savrul, M. and Aydin, O. (2014) Structure of Small and Medium-Sized Enterprises in Turkey and Global Competitiveness Strategies. Procedia-Social and Behavioral Sciences, 150, 212-221. https://doi.org/10.1016/j.sbspro.2014.09.119

[13] Ahmedova, S. (2015) Factors for Increasing the Competitiveness of Small and Medium-Sized Enterprises (SMEs) In Bulgaria. Procedia-Social and Behavioral Sciences, 195, 1104-1112. https://doi.org/10.1016/j.sbspro.2015.06.155

[14] Sag, S., Sezen, B. and Guzel, M. (2016) Factors That Motivate or Prevent Adoption of Open Innovation by SMEs in Developing Countries and Policy Suggestions. Pro- 
cedia-Social and Behavioral Sciences, 235, 756-763.

https://doi.org/10.1016/j.sbspro.2016.11.077

[15] Soltes, V. and Gavurova, B. (2014) Innovation Policy as the Main Accelerator of Increasing the Competitiveness of Small and Medium-Sized Enterprises in Slovakia. Procedia Economics and Finance, 15, 1478-1485. https://doi.org/10.1016/S2212-5671(14)00614-5

[16] Lisowska, R. and Stanislawski, R. (2015) The Cooperation of Small and Medium-Sized Enterprises with Business Institutions in the Context of Open Innovation. Procedia Economics and Finance, 23, 1273-1278. https://doi.org/10.1016/S2212-5671(15)00509-2

[17] Stanislawski, R. and Lisowska, R. (2015) The Relations between Innovation Openness (Open Innovation) and the Innovation Potential of SMEs. Procedia Economics and Finance, 23, 1521-1526. https://doi.org/10.1016/S2212-5671(15)00330-5

[18] Sipa M., Gorzen-Mitka, I. and Skibinski, A. (2015) Determinants of Competitiveness of Small Enterprises: Polish Perspective. Procedia Economics and Finance, 27, 445-453. https://doi.org/10.1016/S2212-5671(15)01019-9

[19] International Trade Center (2017) SME Competitiveness Outlook 2017-The Region: A Door to Global Trade. http://www.intracen.org

[20] Kathimerini (2015) In Seven Years 229,000 Small and Medium Enterprises Went out of Business in Greece.

http://www.kathimerini.gr/824685/article/oikonomia/epixeirhseis/se-mia-eptaetia-e kleisan-229000-mikres-kai-mesaies-epixeirhseis-sthn-ellada 